\begin{tabular}{|l|l|l||}
\hline \multicolumn{2}{|c|}{ PublisherInfo } \\
\hline \hline PublisherName & $:$ & BioMed Central \\
\hline \hline PublisherLocation & $:$ & London \\
\hline \hline PublisherImprintName & $:$ & BioMed Central \\
\hline \hline
\end{tabular}

\title{
The hidden transcriptome
}

\begin{tabular}{|l|l|l||}
\hline \multicolumn{2}{|c|}{ ArticleInfo } \\
\hline \hline ArticleID & $:$ & 4470 \\
\hline \hline ArticleDOI & $:$ & $10.1186 /$ gb-spotlight-20020507-02 \\
\hline \hline ArticleCitationID & $:$ & spotlight-20020507-02 \\
\hline \hline ArticleSequenceNumber & $:$ & 136 \\
\hline \hline ArticleCategory & $:$ & Research news \\
\hline ArticleFirstPage & $:$ & 1 \\
\hline \hline ArticleLastPage & $:$ & 2 \\
\hline \hline & & RegistrationDate : 2002-5-7 \\
\hline ArticleHistory & $:$ & OnlineDate \\
\hline \hline ArticleCopyright & $:$ & BioMed Central Ltd2002-7 \\
\hline \hline ArticleGrants & $:$ & \\
\hline \hline ArticleContext & $:$ & 130593311 \\
\hline \hline
\end{tabular}




\section{Jonathan B Weitzman}

Email: jonathanweitzman@hotmail.com

Analysis of the human transcriptome is often limited to annotated sequences. In the May 3 Science, Philipp Kapranov and researchers at Affymetrix Inc. in California provide evidence for many undiscovered transcribed sequences from human chromosomes 21 and 22 (Science 2002, 296:916-919). Most microarray transcriptome analysis is based on annotated exon sequences. Kapranov et al. took an empirical approach and constructed microarrays containing 25-mer oligonucleotides spaced uniformly every 35 base-pairs along chromosomes 21 and 22. They hybridized these chips with cytoplasmic polyadenylated RNA from 11 different cell lines, and found that the majority of the positive sequences detected transcripts that fall outside of annotated or predicted genes. The authors predict that there may be as much as an order of magnitude greater transcription than is implied by the current annotation, and suggest that this approach could lead to array-guided transcription maps and the discovery of an extensive 'hidden transcriptome' awaiting functional characterization.

\section{References}

1. Science, [http://www.sciencemag.org]

2. Affymetrix Inc., [http://www.affymetrix.com]

3. Experimental annotation of the human genome using microarray technology.

4. Affymetrix Transcriptome Project, [http://www.affymetrix.com/transcriptome] 